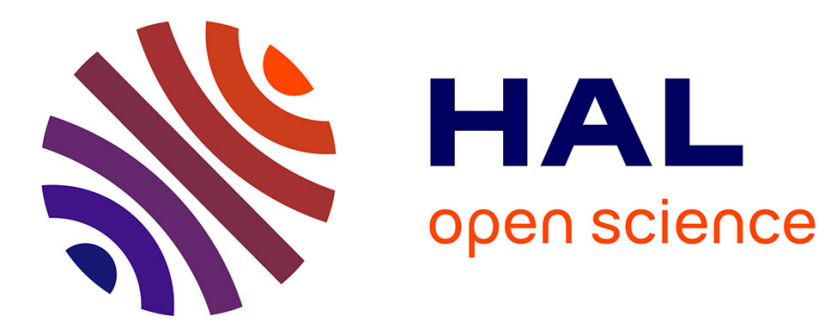

\title{
Toward a Proto-Mande reconstruction and an etymological dictionary
}

Valentin Vydrin

\section{To cite this version:}

Valentin Vydrin. Toward a Proto-Mande reconstruction and an etymological dictionary. Faits de langues, 2016, Comparatisme et reconstruction: tendances actuelles (Dir. K. Pozdniakov), 47, pp.109123. halshs- 01375776

\section{HAL Id: halshs-01375776 https://shs.hal.science/halshs-01375776}

Submitted on 16 Oct 2016

HAL is a multi-disciplinary open access archive for the deposit and dissemination of scientific research documents, whether they are published or not. The documents may come from teaching and research institutions in France or abroad, or from public or private research centers.
L'archive ouverte pluridisciplinaire HAL, est destinée au dépôt et à la diffusion de documents scientifiques de niveau recherche, publiés ou non, émanant des établissements d'enseignement et de recherche français ou étrangers, des laboratoires publics ou privés. 


\title{
Toward a Proto-Mande reconstruction and an etymological dictionary
}

\author{
Valentin Vydrin*
}

\section{THE CONTEXT AND STATE OF THE ART ${ }^{1}$}

The Mande language family includes more than 70 languages $^{2}$ spoken by 45 to 50 million people in 12 countries of West Africa. The most widely spoken and best-known languages, such as Bamana (Bambara), Maninka (Malinké), Jula (Dioula) or Soninke, are spoken by millions or even dozens of millions; some others (such as Goo, Ngen, Wan, Kakabe, etc.) remain almost unknown even in their own countries, and are often endangered. The genetic depth of the Mande family is estimated to be more than 5000 years (Vydrin 2009), which is comparable to the distance between Indo-European branches.

The earliest moves toward Proto-Mande reconstruction date back to the $19^{\text {th }}$ century. First comparative series were proposed by Koelle (1854/1963), Delafosse (1904) and Westermann (1927). An attempt at the systematic reconstruction of the Mande consonant system and vocabulary was carried out by Pozdniakov (1978), and was based on an advanced methodological approach (unfortunately, hampered by the paucity and the low quality of linguistic data available 40 years ago, in comparison to with what we dispose of now). A reconstruction of the consonant system for the Central and Southwestern groups (as a part of an attempt at Proto-Western Mande reconstruction) was carried out by Kastenholz (1996) who suggested 187 lexical reconstructions for the "Central Mande + Southwestern Mande" protolanguage. There are some other important publications of the last decades that deserve mention: (Creissels 1979, 1997, 2004; Dwyer 1973, 1974, 1988; Grégoire 1988; Schreiber 2008).

During the last 20 years, abundant and high-quality data have been accumulated, in line with modern methodological requirements (among them, the openness and the verifiable character of the data and procedures) and with the

* INALCO-LLACAN - Université d'État de St. Petersbourg. Email: vydrine@gmail.com 1 This work is part of the program Investissements d'Avenir, overseen by the French National Research Agency, ANR-10-LABX-0083, (Labex EFL) and of my IUF project. I am thankful to Coleman Donaldson who has checked my English.

273 languages, according to the current edition of the Ethnologue, http://www. ethnologue.com/subgroups/niger-congo. However, this figure should be modified in the view of some recent findings. On the other hand, certain varieties mentioned in the Ethnologue as separate languages should in fact be regarded as dialects of some other languages. 
means provided by computer technologies. Evidently, any modern Proto-Mande reconstruction work should take into account these new possibilities.

\section{MAJOR COMPONENTS OF RECONSTRUCTION: PERSPECTIVES}

\subsection{Internal classification of the Mande family}

There is a relative consensus among specialists about the lower level taxons within the Mande family; there are 11 of them: Manding, Mokole, Vai-Kono, Jogo-Jeri, Susu-Jalonke, Southwestern, Soninke-Bozo, Samogho, Bobo (the latter is represented as one language, but its dialects are considerably diverse and can probably be regarded as distinct, albeit closely related, languages), Southern and Eastern. Most specialists also agree that the latter two groups constitute one branch (Eastern or Southeastern), and all the other groups constitute the other one (Western). The divergences in opinions concern mainly the intermediary stages of classification (and the names of the groups and branches).

The inner classification of Mande has a long history; for a survey see (Kastenholz 1996). As things stand currently, Kastenholz's classification is more or less accepted as standard in most popular reference books, such as the Ethnologue (cf. http://en.wikipedia.org/wiki/Mande_languages). In a recent work (Vydrin 2009), I advanced a different classification. Its major innovations, in comparison with that of Kastenholz, are the following:

- the Soso-Jalonke group is put together with the carthwestern group, rather

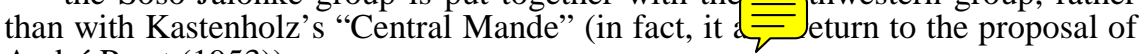
André Prost (1953));

- Soninke-Bozo, Samogho and Bobo are no longer considered as branches of the same genetic unit (Kastenholz's "Northwestern Mande”), but rather as independent groups inside Western Mande;

- the Mokole group is put together with Vai-Kono, rather than with Manding;

- in the Southern Mande group, Mwan is separated from Wan and put together with the Guro-Yaure subgroup;

- San (Samo) is put together with Bisa, rather than with Busa-Boko.

My classification is based on glottochronology. It is true that since its invention in mid-20 century, glottochronology and lexicostatistics have been considerably discredited because of the numerous shortcomings of M. Swadesh's method, to the point that many comparative linguists have grown allergic to the very mention of glottochronology ${ }^{3}$. However, the method of "improved glottochronology" by Sergey Starostin and his team (see, among others, (Starostin S. 1989; Starostin G. 2010)) accounts for the $\equiv$ riticism and makes the glottochronology much more precise. In particular, the "improved" method excludes borrowings from the comparative lists, and it strongly recommends an

${ }^{3}$ Thus, in the English Wikipedia, a reference to my classification has been accompanied with the following comment:

"Most internal Mande classifications are based on lexicostatistics, and the results are unreliable. See for example, Vydrin (2009), based on a 100-word list.” 
in-depth comparative examination of the lists before they are used for the glottochronological purposes. As a result, the method is now much more reliable.

In this regard, for the fragments of the proto-language systems where comparative studies have been done following different methods (e.g., morphological reconstruction of Proto-Southern Mande (see Vydrin 2006, 2012); a detailed etymological examination of the basic vocabulary of Mokole languages, in comparison with Manding and Vai-Kono, see (Vydrin \& Vydrina 2014)), the results of my glottochronological analysis have generally been confirmed.

\subsection{A phonological reconstruction}

It can be subdivided into reconstructions of initial consonants, of word-internal consonants, of vowels, and of tones. Let us consider each of these subsystems separately.

1) Initial consonants yield to reconstruction more easily than word-internal ones, which is why major progress has already been achieved in this domain. So far, initial consonants systems for the following groups have been reconstructed:

- Manding (Creissels 1979; Pozdniakov \& Vydrin 1988; Kastenholz 1996);

- Southwestern Mande (Dwyer 1974; Kastenholz 1996; Vydrin 1989, 2006b);

- Southern Mande (Vydrin 2007; an earlier reconstruction of labial consonants by Claire Grégoire, 1988, is rather outdated).

There is a tentative Eastern Mande reconstruction by Henning Schreiber (2008), although it needs a considerable improvement (see the critique in Vydrin 2010). For the other groups, little has bee accomplished yet.

The studies carried out so far show, however, that a straightforward application of the regular correspondences procedure hardly suffices. Like in reconstruction work for other language families, a linguist often encounters complicated morphophonological processes and has to apply the method of internal reconstruction. In particular, the following cases should be mentioned:

- initial consonants alternation. This alternation is heavily present in the Southwestern Mande languages where two main models are attested: the "Kpelle model" where voiceless consonants become voiced after the nasal element $-\eta$, while oral sonants and implosives are replaced by nasal sonants; and the "MendeLooma model" where the element $-\eta$ tends to disappear at the surface level, but remains at the underlying level and is manifested in the cancellation of the lenition of the subsequent consonant. The mechanism of consonant alternation in the languages of this group has been analyzed in numerous publications by different authors (for a survey, see Kastenholz 1996; Vydrin 1989; Vydrin 2006, 99-114), and is sufficiently clear to this point. However, there remain some open questions, such as the immunity of certain nouns to the initial consonant alternation (a fact that can probably be explained by traces of archaic nasal prefixes, see below), or the attribution of consonant alternation to the protolanguage level. In relation to the latter question, Kastenholz postulates a consonant alternation (apparently, of the "Mende-Looma type") for the ProtoCentral (Manding + Mokole + Vai-Kono + Jogo-Jeli + Susu-Jalonke) level which 
would explain some irregularities in initial consonant correspondences among the languages of the Jogo-Jeli, Vai-Kono, and Manding groups. This hypothesis does not seem to sufficiently grounded to me and needs to be verified on a broader set of data.

- the impact of archaic nasal prefixes. According to the hypothesis formulated in (Pozdniakov \& Vydrin 1986, 1988; Vydrin 1989; Vydrin 2006a), initial prenasalized consonants ( $n p-, n t-, n k-, n s-$, etc.) in Bambara nouns result from fossilization of an archaic nasal prefix. Reflexes of this prefix manifest themselves in perturbations of the initial consonant alternation in Southwestern Mande languages, and they can produce irregular correspondences in the languages of other groups as well. What makes the situation even more complicated is the fact that another nasal prefix with different semantics also needs to be postulated, whose reflexes are not identical (Vydrin 2006a).

- reconstruction of implosive and nasal consonants. Implosive $b$ and $d$ are attested in the majority of Southern Mande languages, they are also present in some Southwestern Mande (Kpelle, Looma, Bandi), in Vai, in some Ivoirian varieties of Manding, where they can be interpreted as a result of recent evolution. As for nasal consonant phonemes, they are broadly represented in the languages of the Mande family, but they are lacking (or are very marginal) in the Southern Mande group (more precisely, nasal consonants are there, but they have no phonological status in most of the languages). Applying the majority rule approach (the share of the languages with implosives in the Mande family), one could think that the implosives is a Southern Mande and Vai innovation and a result of the Southern Mande influence on the Southwestern Mande and Manding; and also, that the loss of nasal consonants is another Southern Mande innovation. However, a typologially-oriented systemic approach suggests another solution: the Southern Mande situation reflects the Proto-Mande one. The presence of implosive consonants in the Proto-Mande and non-phonological status of nasal consonants explains some important irregularities in Western Mande (in particular, a quasi-absence of combination of nasal consonants with subsequent semi-closed vowels, such as mo, me, no, ne, no, ne, no, ne), as shown in (Vydrin 2004, 2006a).

2) Reconstruction of word-internal consonants and vowels turns to be a much more difficult task. So far, there is a reconstruction of the word-internal consonants for the Proto-Manding by Pozdniakov \& Vydrine (1988), for the Proto-Manding and Proto-Southwestern Mande by Kastenholz (1996). As for vowels, only one attempt has been made thus far (Pozdnâkov \& Vydrine 1988); Kastenholz simply renounced the task of the vocalic reconstruction (1996, 140141).

The fact that vowels do not yield easily to reconstruction is common knowledge among comparative linguists, and the situation in Mande languages is further complicated by the phenomenon of metric foot. In the majority of Mande languages, the existence of a foot as a metric unit bigger than a syllable should be postulated; and it cannot be excluded that metric foot was relevant for the Proto- 
Mande as well ${ }^{4}$. A foot is characterized by a strong cohesion of its elements. This cohesion manifests itself in several ways: a reduced inventory of foot-internal consonants in comparison with initial consonants; foot often serves as a domain of vowel harmony, or, at least, there are considerable restrictions on the inventory of vowel combinations within a foot; inventories of tonal contours of a foot are also limited.

Diachronically, one can observe a continuous process of foot-building in many languages: normally a morpheme (even a monosyllabic one) corresponds to a foot, and one foot cannot contain two morphemes. However, once a disyllabic derived or compound word loses the transparency of its internal structure, it can be reinterpreted as a one-foot unit. As a result, word-internal elements become eroded: the Inlaut consonants undergo sonorization or even get omitted; harmonization of vowels and tonal contours takes place.

Word compounding is an extremely productive in all Mande languages, and one can sometimes observe iterative cycles: word compounding $\rightarrow$ loss of transparency of the components and transformation into a one-foot unit $\rightarrow$ monosyllabization (further on, the resulting monosyllabic root can be involved again in word compounding). Southern Mande and Eastern Mande languages are most concerned by this process (it is less visible or even absent in the languages further to the north, such as Soninke); at the same time, it is irregular and rather unpredictable. The reconstruction of their foot-internal elements is therefore extremely difficult. In certain cases, it is still doable, e.g.: ${ }^{5}$

Dan $z \bar{u} \mathrm{n}$ 'behind', $z \bar{u}-k p \bar{\gamma} \mathrm{n}$ 'buttocks', Mano $z \bar{i}-k p \bar{o} \mathrm{n}$ 'behind', Guro $z \bar{u} \bar{o} \mathrm{pp}$ 'after, behind', Gban zi n lower part of buttocks', Mwan $z \bar{i}$ rn 'buttocks', pp 'behind'.

In this comparative series, the vowels of the Guro form $z \bar{u} \bar{o}$ seem to be inexplicable in comparison with Dan $z \bar{u}$, Gban zì, Mwan $z \overline{\text { l }}$. However, if we consider the compound forms Dan $z \bar{u}-k p \bar{\gamma}$ litt. 'behind-ball', Mano $z \bar{i}-k p \bar{o}$ (the same), it can be suggested that the Guro form $z \bar{u} \bar{o}$ might be by origin a contraction of a compound ${ }^{*} z \bar{i}-p \bar{o}<*^{*} z \bar{i}-k p \bar{o}$, and in this case the ProtoSouthern Mande form could be reconstructed as ${ }^{*} z i$ (the nasalization in Gban is yet to be explained).

However, in many other cases the root that could be indicative of the nature of the fused element is missing in the modern languages. As a result, one should expect the reconstruction of vowels to be rather fragmentary and hard to prove. However, a systematic typological approach to Proto-Mande vocalic reconstruction can be helpful. As it was shown in (Vydrine 2004), there is

${ }^{4} \mathrm{My}$ interpretation of the metric foot in Mande languages is presented, in particular, in (Vydrine 2001, 2010). It is different from the vision of foot found in more formalist works by American linguists (e. g., Leben 2003; Green 2010, 2013; Weidman \& Sharon 2006); however, there are common elements in our approaches.

5 In the fragments of the Mande Etymological Dictionary, the names of languages, abbreviations for dialects and for sources are given in bold, the forms are italicized, and their translations are in Roman type. 
indirect evidence (the same as for the implosive consonants and lacking nasal consonants) that the Proto-Mande had vowel harmony (presumably, the domain of the harmony was a metric foot) with three series: +ATR, -ATR, and nasal ( similar to what is observed in modern Guro and Yaure languages of the Southern group). Various vocalic systems attested in modern Mande languages result from the transformation of this original system.

3) Tonal reconstruction. So far, little has been done in this field; one can mention only David Dwyer's dissertation (1973) on the reconstruction of tone on nouns in the Southwestern Mande group, and Le Saout's (1979) ideas on tonal split in Guro. More recently, a promising study was performed by Maria Konoshenko (2011); some interesting ideas were formulated in (Green, Andersen, Obeng 2013). On the other hand, we now have numerous synchronic descriptions of tonal systems of Mande languages; in many cases, these are high-quality analytic works whose interpretations open perspectives to a diachronic analysis that would have been impossible twenty or even fifteen years ago (cf. a survey of tonal systems of Mande languages in Vydrine 2002, which is now outdated in many respects).

Here are some issues that require further research in relation with the ProtoMande tonal reconstruction:

- tonal inversion. This is a phenomenon not unknown in Africa (about tonal inversion in Bantu languages Luba and Ruwund, cf. in particular Hyman 2001). In the Mande family, there is a whole set of instances of tonal inversion: varieties of Marka-Dafing, Manya, Odjenne Jula in the Manding group (with some reserves, one can add other varieties to this set some as well, such as Nyokolo Maninka, Konyanka, certain varieties spoken in north-western Cote d'Ivoire); Looma in the Southwestern Mande group. Tonal inversion does not present a great difficulty for a mechanical reconstruction (the "inverse" correspondence to the tones of the proto-language being more or less regular), however, this phenomenon deserves special attention, and extra efforts are necessary in order to clarify its diachronic mechanism.

- diachronic processes of the formation of polytonous systems in the languages of Southern Mande, Eastern Mande, Samogho groups and in Bobo. According to the dominant hypothesis of today, the tonal system of ProtoMande had two tones, high and low (the questions of the domain of tone and of contextual rules remain open). The tonal system of Guro (3 level tones and 2 contour tones) keeps strong traces of a two-level tone system which has transformed into a 3-level one through a tonal split caused by tone-depressing consonants (le Saout 1979 ; Vydrine 2003). The reconstruction of the tonal split is a strong argument for the hypothesis of a 2-level system in the ProtoSouthern Mande. However, there is not a single modern language in this group that has retained such a system; most of them have 3 level tones, some others (Dan-Blo, Kla-Dan, Tura, Goo, Gban, Yaure) have 4 level tones, and DanGweetaa has 5 level tones (apart from the contour tones). Tonal correspondences among the languages of "polytonouns" groups are yet to be established. It can be supposed that, apart from the tone-depressor consonants, another important factor for the proliferation of tones was the aforementioned 
process of compression of disyllabic (or polysyllabic) structures into one-foot units; however, its details are yet to be clarified.

- grammatical tones: in the majority of Mande languages, grammatical tones are available. They may express TAM meanings on verbs, sometimes syntactic status of a word or a clause. Often enough, grammatical tones can be traced back to segmental morphemes (cf. some examples in Vydrin 2012); however, it may be that certain tonal morphemes might have existed as such at earlier stages to be reconstructed.

- domain of tone and tonal compactness: ${ }^{6}$ Mande languages diverge considerably with this respect. In the Manding group, we find extreme cases of grammaticalized tonal spread rightwards; in these languages, there is a strong tendency to extension of tonal domain up to the limits of a word and even of a syntactic group. Another extremity is represented by Southern Mande languages where tonal domain is usually a syllable, although there are, in most languages, limitations on combinations of tones in a heavy metric feet. Languages of other Mande groups lie somewhere between these extremities.

The tonal compactness in Manding languages can be also interpreted as a grammatical operation marking a syntactic relation in nominal constructions: on the dependent word, in the case of an attributive construction, and on the head word, in the case of a genitive construction. However, instances of tonal marking of the same syntactic relations are also attested in many other groups of the Mande languages: Southwestern, Susu, Soninke, Southern (to mention just the well described cases). It is quite probable that some kind of tonal marking of these relations could be reconstructed at the Proto-Mande level; research in this direction seems to have good perspectives.

\subsection{Morphological reconstruction}

Recently, a hyper-rigorous approach has grown quite popular; even if it cannot be regarded as the mainstream in the comparative linguistics, it has acquired authority among the broad masses of linguists who are not directly engaged into reconstruction work (and who outnumber the comparativists by far) and cannot therefore be disregarded. In the argumentation of the proponents of this approach, morphological reconstruction is a sine qua non in the establishment of genetic relationship among the languages:

(the diagnostics of relatedness...) "does not rely on vocabulary... The diagnostic evidence is grammatical, and it combines structural paradigmaticity .... and syntagmaticity with concrete morphological forms. ... Classic lexical comparison and reconstruction are then quite limited in their possible achievements: They can only describe and extend relatedness but cannot establish it” (Nichols 1996, 64).

6 Tonal compactness (in French, compacité tonale) is a phenomenon of Manding languages broadly discussed by specialists; see Creissels (1992), Dumestre (1987), etc. What is meant by tonal compactness in Mande linguistics is a spread of the lexical tonal contour of the initial word of certain syntactic constructions on the subsequent word(s), e.g. (Bambara): só 'house', bilen 'red' $\rightarrow$ só bílen 'red house'. 
If we try to apply the "hyper-rigorous" approach to the Mande languages, we run the risk of becoming disappointed: it turns out that even in relatively morphology-rich groups of the Mande family (in comparison with the Manding languages which are extremely isolating), nearly all morphological markers are of innovative nature, and very little morphology can be reconstructed even for a low-level proto-language (2000-3000 years deep), let alone the Proto-Mande level. And if one insists on the necessity of the reconstruction of paradigmatic grammatical features, the Mande family could hardly be recognized as a genetic unit. An alternative option would be to recognize that the "hyper-rigorous" approach (in its current version) does not take into account the specificity of isolating languages ${ }^{7}$.

However questionable might be the morphology as the criterion sine qua non for the genetic relationship among the Mande languages, it is out of question to exclude it from the comparative analysis. Morphological reconstruction, both internal and external, is quite fruitful for low-level groups, and besides, this work provides much of the very interesting data for the theory of grammaticalization (cf. a tentative reconstruction of the TAM morphology for the Proto-Southern Mande in Vydrin 2012).

In fact, there are some traces of ancient morphology in Mande languages: prenasalized initial consonants in certain Manding languages and irregularities in the initial consonant alternations in Southwestern Mande; various plural markers; and some others (for a detailed analysis, see Vydrin 2006a; a hypothesis on the origin of these elements from noun class markers is to be verified). Proto-forms of these morphemes are most often difficult to reconstruct, as well as their morphosyntactic statuses, although further efforts in this direction could probably bring interesting results.

The main topics for the morphological reconstruction of Proto-Mande are the following:

- pronominal systems. Reconstructions of the proto-systems for the Southern Mande and Southwestern Mande have already been done, although some corrections may be necessary taking into account new data and interpretations. "Heavy" systems (with numerous pronominal series, each series expressing some TAM, polarity, case or communicative status meanings) also exist in Eastern Mande, Samogho, and Bobo. In the other groups, pronominal systems are "light", and their reconstruction will not be too time-consuming.

- noun morphology. Apart from the fossilized prefixes (mentioned above and analyzed in detail in Vydrin 2006a), there are also multiple plural markers which can be probably brought back to the Proto-Mande level. Analysis of the nominal declination in some Southern Mande languages (especially Dan and Goo, see Vydrine 2011, 2013) is of major interest for the theory of grammaticalization, however, it can hardly contribute seriously to the reconstruction of the protolanguage. ${ }^{7}$ For a critique of the hyper-rigorous approach, see in particular (Starostin G. 2013: 30-
57). 
- TAM. Grammatical semantics of the TAM and polarity zone are expressed in Mande languages mainly by auxiliary words ("predicative markers", according to the established Mandeist tradition) in the post-subject position, often in combination with verbal suffixes. The "predicative markers" may be of various origins: often enough, they go back to copulae of situative non-verbal sentences ${ }^{8}$, and in Southern, Southwestern and Eastern Mande languages they merge easily with subject pronouns. Verbal suffixes arise, most often, from locative postpositions. It is not rare that TAM meanings are expressed by tonal morphemes on the verb (see above). The grammatical tones can often be derived diachronically from verbal suffixes. A full evolution path can be represented as follows: postposition $\rightarrow$ suffix of a participle/converb/infinitive/supin $\rightarrow$ verbal suffix $\rightarrow$ tonal morpheme on the verb. A diachronic analysis of the TAM system of South Mande languages was done in (Vydrin 2012); for a survey and a diachronic analysis of the Manding TAM, see (Tröbs 2004, 2009). For the other groups, such an analysis is yet to be done.

- "verbal extensions" (derivative suffixes) represent a very prominent feature of most of the families within the Niger-Congo phylum (Hyman 2014). It is generally admitted that Mande languages have no "verbal extensions", which is not quite exact: there are some derivative suffixes (a causative suffix $-b \varepsilon$ in Bobo; a causative suffix $-k a$ in Gban; causative suffixes $-n d i$ in Soninke and Mandinka and - $n i$ in Bozo; an antipassive suffix - ri in Mandinka, cf. Creissels \& Sambou 2013, 392-393). Most likely, these suffixes (with the exception of - ndi, $n i$ and $-r i$ ) represent recent innovations, however, they should be taken into consideration in the reconstruction of the proto-languages of intermediary stages.

\subsection{Etymological dictionary}

I have been working on my etymological dictionary of the Mande family for almost 30 years. During all of that time, it has been consistently fed both by old data from ancient sources, and by field data collected by myself or by students and researchers, members of my field team working since 2001 in Côte d'Ivoire, Guinea and Mali.

For 14 years the dictionary has existed in an electronic form (in Toolbox format, convertible into other database formats). For this dictionary, I have assumed a rather maximalist approach; the following types of information are included:

- references to the sources of information (in the form of two-letter indexes; the full lists of the indexes and the sources are available in an accompanying file);

- dialectal marks (for the languages whose data are represented by two or more dialects);

\footnotetext{
${ }^{8}$ Cf. the hypothesis by Denis Creissels (1997) on the evolution of some "predicative markers" from postpositions. This hypothesis, although very elegant and tempting, needs further corroboration.
} 
- irregular morphological forms (even if the majority of Mande languages have little morphology, there are some exceptions);

- full information on the semantics of each lexeme in each language; for polysemous lexemes, all the senses are given. On one hand, this provides information necessary for a semantic reconstruction; on the other hand, the polysemy model may serve as an argument for (or against) the etymological identity of lexemes in different languages;

- information on verbal valencies (intransitive, transitive, reflexive character of the verb; postpositions or prepositions introducing the indirect object).

By the end of November 2014, the number of entries in the dictionary was 3445. An entry in the dictionary represents one root that can be potentially reconstructed for a proto-language (not necessarily Proto-Mande; it may be a proto-language of a lower level), with all its reflexes in modern languages. I also include borrowings (most often from Arabic, sometimes from African languages outside the Mande family; naturally, the form and the meaning of the source language are also given), because borrowings can provide valuable information on the history of the languages too.

So far, data of the following groups have been introduced: Southern Mande, Southwestern Mande, Soso-Jallonke, Soninke-Bozo. Manding data have been introduced to a great degree. The evidence from the other groups of the family (Vai-Kono, Mokole, Jogo-jeri, Bobo, Samogho, Eastern Mande) have been partially introduced and a continuous effort will be necessary in order to process the lexicographical sources for these languages.

Reconstructed forms are more or less systematically given for ProtoSouthwestern Mande and, partially, Proto-Southern Mande and Manding. Reconstructions for the other intermediary proto-languages (and, eventually, the Proto-Manding) will be introduced as I go along in my phonetic and lexical reconstructions. Here are two sample entries from the Mande Etymological Dictionary, 'to marry' and 'meal'. Names of the languages are given in bold, abbreviations for dialects are in brackets, two-letter abbreviations in capitals stand for the sources. Each Mande group is represented by a separate paragraph.

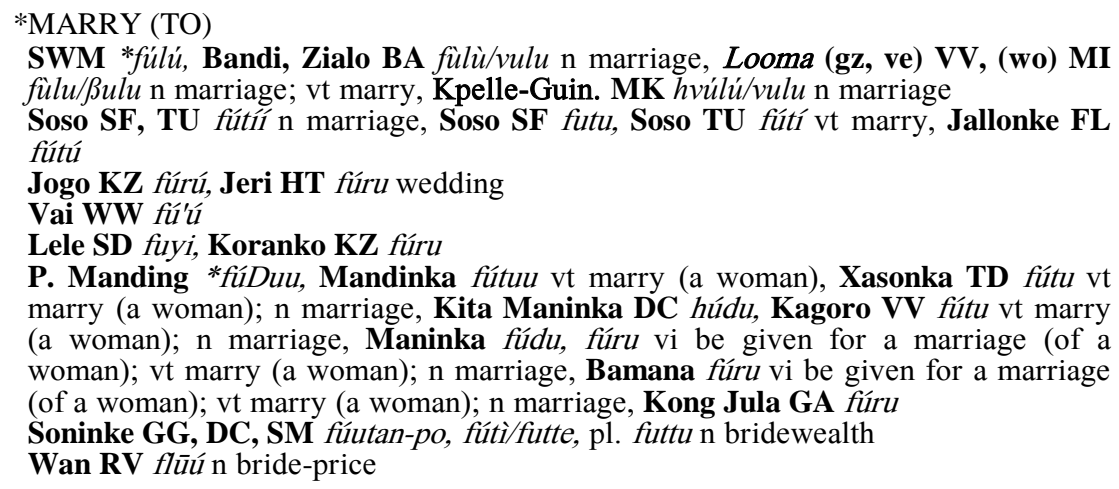


*MEAL

SWM *kóNdón, Mende IN kóndó/? n food prepared for workers, Bandi, Zialo BA

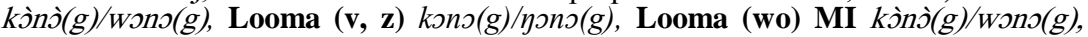
Kpelle-Lib. KE2 kónón/gonon n food, food supplies; vt feed, Kpelle-Guin. MK kónón'/gonon, Kpelle-Guin. (kn) kóron/goron n food, meal; feast

Jallonke FL qóńtóń n meal for farm workers

Mandinka CD kónton n midday meal, lunch, Xasonka TD xóntọ vr have a lunch (midday meal); n midday meal, Maninka kóndón n meal brought to workers to the farm; reward for a work, Bamana kón’ó, kònó n rebate (a supplement given by a vendor to a customer); vt give a supplement to a customer

Sorogama LA kùú (?) n meal

Dan (gw) kó̆́n n food; staple food, Mano (g) KH kónón food (< Kpelle?)

It is planned to continue work on this dictionary with the tools provided by the Reflex lexical database.

\section{MANDE AND NigER-CONGO}

The Mande language family was postulated in mid- $19^{\text {th }}$ century by Sigismund Koelle (1854/1963). Its unity has never been seriously questioned, however, its external classification was subject of numerous discussions. Joseph Greenberg classified Mande with the Niger-Congo (or Congo-Kordofanian) languages which was more or less generally accepted until the recent upsurge of "NigerCongo skepticism” whose proponents (Güldemann 2008, Dimmendaal 2008) contest the inclusion of "peripheral" families (Mande, Ubangi, sometimes Ijo, Dogon, Kordofanian; the list varies among the authors) into Niger-Congo. The major objections against the Niger-Congolese origin of Mande are its lack of common morphology with other families of the macrofamily (first of all, noun classes, the feature which is very well represented in Niger-Congo), and the paucity of a common lexicon.

It is evident that the genetic distance between Mande languages and the "Narrow Niger-Congo" languages is more considerable than the distance between the families within the "Narrow Niger-Congo" grouping. However, when comparing the list of the 20 most stable Niger-Congo roots (Pozdniakov 2013) with Proto-Mande pre-reconstructions (see Table 1), it turns out that only two Mande roots (which are given in Table 1 in bold) are definitely different from the Niger-Congo roots; four others (in italics) are "week candidates" (they are either too divergent in their forms from the Niger-Congo roots, or little represented in the Mande family). Fourteen roots (in regular type) are good or even very good candidates for cognates with reflexes of the Proto-Niger-Congo roots. 
Table 1. 20 most stable Niger-Congo roots compared with Proto-Mande pre-reconstructions ${ }^{9}$

\begin{tabular}{|c|c|c|c|c|c|}
\hline & $\mathrm{NC}$ & Mande & & $\mathrm{NC}$ & Mande \\
\hline two & *ba-di & *Pìi-da(y) & COW & *nak & *nìnka (W) \\
\hline three & ${ }^{*}$ Tati/Tatu & $\begin{array}{l}\text { (*sàgba, } \\
\text { *yàaka) }\end{array}$ & human & $*^{n} \mathrm{nu} / \mathrm{ni}$ & *núu (SW) \\
\hline four & *nai /na 1 & *náanì (W) & black & $\mathrm{bi}(\mathrm{D}) / \mathrm{bi}(\mathrm{N})$ & *Pì (W) \\
\hline tongue & $* \mathrm{dem} / \mathrm{lem}$ & *légV & chicken & *čoke & $*$ tog $\varepsilon$ \\
\hline tree & ${ }^{*} t e / t i$ & ${ }^{*}$ yíti & $\begin{array}{l}\text { grandparent, } \\
\text { child }\end{array}$ & *mama & *màmá (W) \\
\hline $\operatorname{dog}$ & *buha & *gbÉlàn (?) & tooth & *nin & *nín \\
\hline to eat & ${ }^{*} D i$ & $\begin{array}{l}* d E \\
\text { (spurious) }\end{array}$ & to cough & $*_{\text {tu }}$ & (*tiso) \\
\hline mother & *na/ni & *dã & sand & $*$ cengi & *kغ̀gV \\
\hline white & *pu(D) & *púlú & to bite & *dum/lun & $\begin{array}{l}\text { *dóbũ / *dOn } \\
\text { 'eat' }\end{array}$ \\
\hline skin & *kwoto & *kpoLo & to pound & $*$ to & $\begin{array}{l}\text { *tùgu (Vai- } \\
\text { Mokole) }\end{array}$ \\
\hline
\end{tabular}

Of course, this comparative list is very preliminary, it can by no means be regarded as definite proof of the Mande family belonging to Niger-Congo. However, it shows that the overly rigorous approaches of "splitters" should be regarded with as much caution as the too lax approaches of "lumpers". In fact, both extremes are born by a situation where true and reliable reconstructions are rare, where judgments are often based on comparison of modern languages forms (rather than reconstructions of intermediate levels) or on typological criteria (e.g., in the case of Mande, the absence of noun classes).

It means that a detailed reconstruction of the Proto-Mande language, based on strict methodological principles (in particular, on the step-by-step principle), is necessary. Without such reconstruction any polemics on the limits of the NigerCongo phylum is barren. When discussing the question of belonging (or not belonging) of Mande to Niger-Congo, we can represent the logic as follows: if the differences among related languages are proportional to the genetic distances, and if Mande languages belong to the Niger-Congo, then the Proto-Mande must resemble Proto-Gur or Proto-Kru more than, for example, modern Bambara, modern Mooré or Bété resemble each other, as far as the time distance between the Proto-Mande and Proto-Gur/Proto-Kru is by 10,000 or 12,000 years shorter than that between Bambara and Mooré/Bété. If, on the contrary, stepping back in time (offered to us by linguistic reconstruction) does not suggest approaching, then the language families are not related.

If the position of Mande within Niger-Congo is confirmed (and in this case, Mande will certainly represent the most ancient branching of the phylum), the Proto-Mande data will acquire a primary importance for the reconstruction of

9 In the Mande column, (W) stands for Proto-Western Mande, (SW) for ProtoSouthwestern Mande. Absence of a mark signifies that the root is represented in both big branches of Mande (Western and Southeastern) and can be therefore reconstructed for Proto-Mande. 
Proto-Niger-Congo: logically, each Proto-Mande root whose cognate is found in any other intermediary proto-language can be brought back to the Proto-NigerCongo level.

\section{BIBLIOGRAPHY}

Creissels D., 1979, Etude comparative du consonantisme de deux parlers manding (Mandinka - Bambara), Bulletin de phonétique de Grenoble VIII, p. 99-155.

Creissels D., 1992, Denis. Tonologie du bambara: bilan et perspectives, Mandenkan (Paris) 24, pp. 1-45.

Creissels D., 1997, Postpositions as a possible origin of certain predicative markers in Mande, Afrikanistische Arbeitspapiere 50, p. 5-17.

Creissels D., 2004, L’occlusive vélaire sonore $g$ et les labio-vélaires ( $w, g w, k w$, $g b, k p$ ) en mandingue, Mandenkan (Paris) 39, p. 1-22.

Creissels D. \& Sambou P., 2013, Le mandinka. Phonologie, grammaire, textes, Paris, Karthala.

Delafosse M., 1904, Vocabulaires comparatifs de plus de 60 langues et dialectes parlés à la Côte d'Ivoire et dans les régions limitrophes, avec des notes linguistiques et ethnologiques, Paris, E. Leroux.

Dimmendaal G. J., 2008, Language ecology and linguistic diversity on the African continent, Language and Linguistics Compass 2:5, p. 840-858.

Dumestre G., 1987, Le bambara du Mali : Essai de description linguistique, Paris, INALCO, Thèse de Doctorat d'Etat.

Dwyer D., 1973, The comparative tonology of Southwestern Mande nominals, Michigan State University, Ph.D.

Dwyer D., 1974, The historical developement of Southwestern Mande Consonants, Studies in African Linguistics, $5: 1$, p. 59-94.

Dwyer D., 1988, Towards Proto-Mande morphology. Mandenkan (Paris) 14/15, p. 139-152.

Green Ch. R., 2010, Prosodic phonology in Bamana (Bambara): Syllable complexity, metrical structure, and tone, Ph. D. dissertation, Indiana University.

Green Ch. R., 2013, Formalizing the prosodic word domain in Bambara tonology, Journal of West African Languages, 40:1, p. 3-20.

Green Ch., Anderson J. \& Obeng S., 2013, Internal tonal processes in Susu, Mandenkan 50, p. 61-84, Paris.

Grégoire Cl., 1988, An Attempt to Reconstruct Labial Consonants in Mande, in M. Dominicy \& J. Dor (eds.), Phonological reconstruction, problems and methods, Belgian Journal of Linguistics 3, Bruxelles, Editions de l'Université de Bruxelles, p. 101-155.

Grégoire Cl. \& de Halleux B., 1994, Etude lexicostatistique de quarante-trois langues et dialectes mande, Africana Linguistica XI, Annales du Musée Royal de l'Afrique Centrale, Sciences Humaines 142, Tervuren, p. 53-71.

Guldemann T., 2008, The Macro-Sudan belt: towards identifying a linguistic area in northern sub-Saharan Africa, in B. Heine \& D. Nurse (eds.), A Linguistic Geography of Africa, Cambridge, Cambridge University Press, p. 151-185.

Hyman L., 2001, Privative Tone in Bantu, in S. Kaji (ed.), Cross-linguistic studies of tonal phenomena, Tokyo, Institute fort he study of languages and cultures, p. 237-257. 
Hyman L., 2014, R Reconstructing the Niger-Congo verb extension paradigm, in M. Robbeets \& W. Bisang (eds.), Paradigm Change: In the Transeurasian languages and beyond, Amsterdam, John Benjamins, Studies in Language Companion Series 161, p. 103-126.

Kastenholz R., 1996, Sprachgeschichte im West-Mande. Methoden und Rekonstruktionen, Köln, Rüdiger Köppe Verlag.

Koelle S., 1854/1963. Polyglotta Africana, London, Church Missionary House, repr.: Graz (Österreich), Akademische Druk und Verlangsanstalt.

Konoshenko M., 2011. Tonal systems in the Kpelle dialects, in V. Vydrin (ed.), Mandeica Petropolitana II. Acta Linguistica Petropolitana VII-2, p. 118173.

Leben W. R., 2003, Tonal feet as tonal domains, in J. Mugane (ed.), Trends in African Linguistics 5: Linguistic typology and representation of African languages, Trenton, Africa World Press, p. 129-138.

Le Saout J., 1979, Notes sur la phonologie du Gouro (zone de Zuénoula), Nice, C.E.P.L.A.N.

Nichols J.. 1996. The Comnarative Method as Heuristic. in M. Durie \& M. Ross (ed.). The Comparative Method Reviewed: Regularity and Irregularity in Language Change, Oxford University Press.

Pozdniakov K., 1978, Mande languages: A comparative and historical analysis, $\mathrm{PhD}$ Thesis, Moscow: Institute of Linguistics, Russian Academy of Sciences (in Russian).

Pozdniakov K., 1991, Perspectives of comparative studies on the Mande and West Atlantic: An approach to the quantitative comparative linguistics, Mandenkan 22, p. 39-69.

Pozdniakov K., 1993, Comparative grammar of Atlantic languages, Moscow, Nauka (in Russian).

Pozdniakov K., 2013, Niger-Congo languages, Russian Great Encyclopaedia 18 (in Russian), p. XXXXX.

Pozdnâkov K. \& Vydrine V., 1986, Die Entwicklung des phonetischen Systems des Pramanden: Nasalitat und Entwicklung des phonologischen Systems des Manden-Sprachen, Zeitschrift für Phonetik, Sprachwissenschaft und Kommunikationsforschung 39-5, p. 549-561.

Pozdnâkov K. \& Vydrine V., 1988. Rekonstruktion des phonologischen Systems des Pramanden, Zeitschrift für Phonetik, Sprachwissenschaft und Kommunikationsforschung 41-3, p. 353-371. 